\title{
Analysis of physico-chemical parameters of salt pans at Newport and Nari situated around Bhavnagar Coast
}

\author{
Apexa Patadia, Bharti P. Dave
}

Department of Biotechnology, Shree M. \& N. Virani Science College, Saurashtra Unviersity, Rajkot, India

$\begin{array}{ll}\text { Received: } & 26.08 .2015 \\ \text { Revised: } & 11.10 .2015 \\ \text { Accepted: } & 29.10 .2015 \\ \text { Published: } & 30.10 .2015\end{array}$

Address for correspondence: Department of

Biotechnology, Shree M. \& N.

Virani Science College,

Saurashtra Unviersity, Rajkot

India.Email: apexasoni6@

gmail.com

\begin{abstract}
The present study was carried out to evaluate physico-chemical parameters of two selected sites of salt pan ecosystem located at Bhavnagar coast, Gujarat for a period of 1-year from December 2005 to August 2006. The analytical data obtained from samples become more informative if supplemented with information concerning the sampling site. Hence, the present work is aimed at the assessment of various physical and chemical parameters of water and sediment samples of salterns at Newport and Nari along Bhavnagar coast, Gujarat. The physico-chemical characteristics include temperature, $\mathrm{pH}$, turbidity, salinity, alkalinity, total hardness, total dissolved solids, chloride, calcium, magnesium, sodium, potassium, sulfate, and phosphate. The results of various physico-chemical characteristics indicate that with most of the parameters examined the contents recorded were higher in water samples as compared to sediments and also the values were higher at Newport than at Nari. A notable observation was with total hardness and sulfate, where the contents were higher in sediments, and the alkalinity, calcium, and magnesium contents were higher at Nari than at Newport. The data were subjected by Karl-Pearson correlation coefficient to examine the co-relationship between and among various physical and chemical parameters using SPSS 15.0.
\end{abstract}

KEY WORDS: Newport and Nari, physico-chemical parameters, salinity, sodium, total dissolved solids, turbidity

\section{INTRODUCTION}

Environmental conditions and physical parameters do affect microorganisms qualitatively and quantitatively. A study of the physico-chemical characteristics is a prerequisite in understanding the habitat and the organisms that inhabit such niche. It also provides an understanding of the aquatic habitat and the requirements of that habitat for growth in laboratory conditions.

Extreme environments have been defined as those in which low species diversity is found and where whole taxonomic groups are missing. They are produced by the action of environmental factors that reach values far from the average in the biosphere. However, sometimes a given factor can reach very different values above those considered normal, creating different degrees of extreme conditions. Thus, it is interesting to study as many of these different degrees as possible since the organisms inhabiting them can also be very different (Brock, 1979). A typical example of this kind of environmental factor is a hypersaline environment that originates by the evaporation of sea water. The hypersaline ecosystem, such as salt marshes, salt pans, and salt lakes, shows a great variability in total salt concentration, ionic composition, and $\mathrm{pH}$. These salterns provide a diversity of environments where different conditions of salinity, $\mathrm{pH}$, temperature, light intensity, oxygen, and nutrient concentrations are found, allowing the study of different microbial communities (Gunde-Cimerman et al., 2000; Pedrós-Alió et al., 2000; and Pedrós-Alió, 2004).

\section{Scope of Study}

The hypersaline environments are important for both surface extension and ecological significance (Le Borgne et al., 2008) and understanding of the physico-chemical characteristics of the habitat is a prerequisite as it affects the biological components, to a great extent. Bhavnagar district is renowned and is a largest producer of salt from brine, and salt making is the livelihood for the residents of this district. The prepared salt is used locally for domestic 
consumption as fertilizer, as soil conditioner, as repellent, in ice plants, etc. As microbial diversity is strongly influenced by physical and chemical parameters and analytical data obtained from samples become more informative if supplemented with information concerning the sampling site, the present work is aimed at the assessment of various physical and chemical parameters of water and sediment samples of salterns at Newport and Nari along Bhavnagar coast, Gujarat during the period from December 2005 to August 2006 at quarterly intervals.

\section{Objectives}

- To assess the various physical and chemical parameters of water and sediment samples of salterns at Newport and Nari along Bhavnagar coast, Gujarat.

- To analyze the effect of seasonal variation in the physical and chemical parameter due to regular and periodic changes in climate synchronized with a season that ultimately reflects the environmental parameters.

- To examine the data for co-relationship between and among various physical and chemical parameters using Karl-Pearson correlation coefficient using SPSS. 15.0.

\section{MATERIALS AND METHODS}

\section{Study Area}

Bhavnagar is located near the Gulf of Cambay in the Arabian Sea, a part of Saurashtra Peninsula, in the central part of Gujarat. Its geographical location is $21.47^{\circ}$ North (Latitude) and $71.15^{\circ}$ East (Longitude) and is selected as the study area. Bhavnagar is a coastal city in the eastern coast of Saurashtra, also known as Kathiawar, located at $21^{\circ} 46^{\prime} \mathrm{N} 72^{\circ} 09^{\prime} \mathrm{E} / 21.77^{\circ} \mathrm{N} 72.15^{\circ} \mathrm{E}$. It has an average elevation of $24 \mathrm{~m}$ (78 ft). It occupies an area of $53.30 \mathrm{~km}^{2}$. General slope dips in the northeasterly direction at the apex of Gulf of Khambhat. The Gulf comprises an area of high tides and is characterized by the domination of strong tidal currents. The tidal currents have mainly been responsible for most of the depositional and erosional features of the Gulf. The topography of the Gulf bottom comprises numerous underwater ridges, deep channels, and shoals (Charatkar et al., 2005).

The coast of the Gulf of Khambhat is enclosed by a number of estuaries, mud flats, salt marshes, islands, cliffs, and mangrove forests. The Gulf is characterized by a number of large and small estuaries appearing as if enclosed within a large one.

Marine salterns are manmade systems where the evaporating sea water is sequentially pumped through as succession of ponds with increasing salinity (Ollivier et al., 1994). They are artificial, extreme environment consisting of a discontinuous salinity gradient, which are commercially operated for producing $\mathrm{NaCl}$. About 10,000 salt-production sites exist in India. Major saline habitats studied in the country are Sambhar Salt Lake (Rajasthan); coastal regions of Gujarat, Tamil Nadu, Maharashtra, Andhra Pradesh, Odisha, and West Bengal. Major salt-producing sites in Gujarat are coastal regions of Kutch and Saurashtra at Kandla, Jamnagar, Maliya, Mithapur, Porbandar, and Bhavnagar (www.nutritionfoundationofindia.org; www. indiainfoline.com). Bhavnagar is the largest producer of salt, with 35,000 tons of salts being produced annually in the district. Like other salterns, the salt pans at Newport and Nari around Bhavnagar coast also consist of a series of interconnected ponds in which the concentration of salt increases as sea water evaporates by solar radiations.

Newport: It is a working port north-east of Bhavnagar. Bhavnagar coast is a muddy coastline of Gulf of Khambhat (Cambay), situated between Latitude $21^{\circ} 45^{\prime} \mathrm{N}$ and Longitude $72^{\circ} 14^{\prime} \mathrm{E}$. The backwaters at this port flow into the salt pans (Figure 1).

Nari: It is a low - lying area, located at $22^{\circ} 10^{\prime} \mathrm{N}$ and $72^{\circ} 15^{\prime} \mathrm{E}$ on the western and northern coasts of the Gulf of Khambhat, Arabian sea about 25-30 km north to Bhavnagar. It thus receives backwaters of Gulf of Khambhat during high tide.

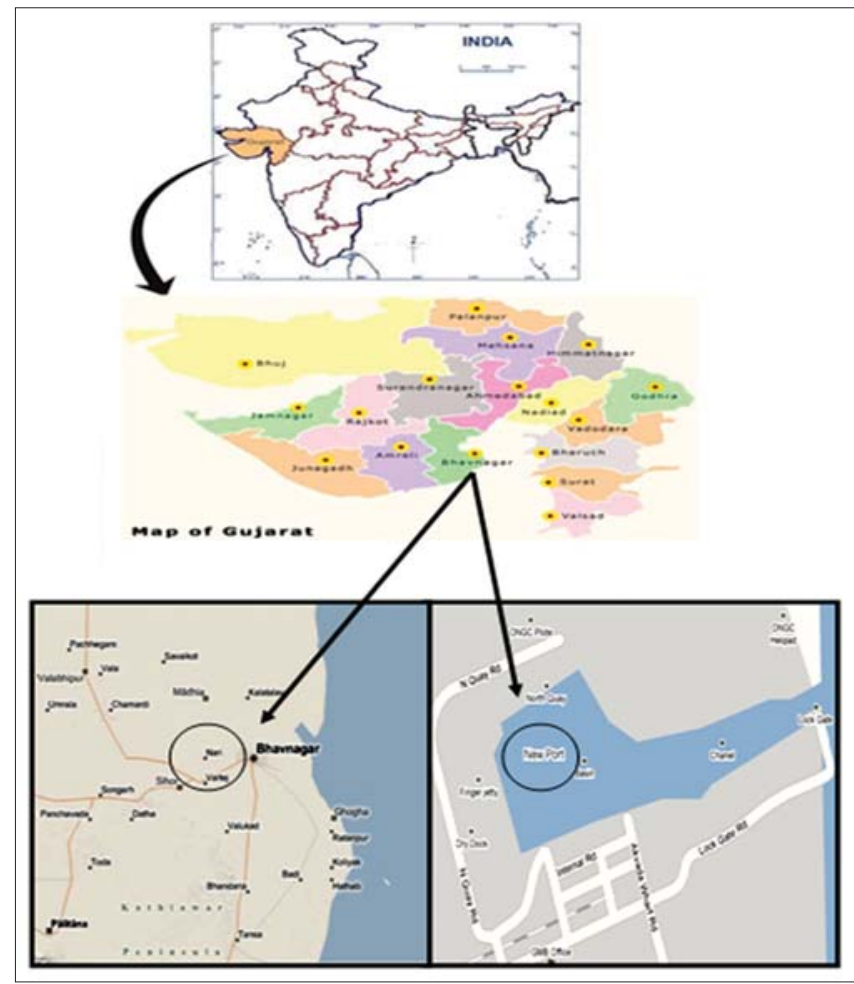

Figure 1: Sites selected for the study 
It has numerous salt pans. The habitat is highly saline, and the soil is mainly silty clay (Figures 1 and 2).

\section{Collection of Samples}

Water and sediment samples from salt pans at Newport and Nari were collected at quarterly intervals during the period from December 2005 to August 2006. The water samples were collected in sterilized glass bottles, and sediment samples were collected in sterilized polythene bags. The samples were brought to the laboratory in an ice-box and analyzed within $6 \mathrm{~h}$ of collection.

\section{Physical and Chemical Analyses}

The methods used were as given in Standard Methods for the Examination of Water and Wastewater, APHA, 2005. The physico-chemical parameters examined were $\mathrm{pH}$, temperature, turbidity, salinity, alkalinity, total hardness, total dissolved solids (TDS), chloride, calcium, magnesium, sodium, potassium, sulfate, and phosphate.

\section{Temperature}

The temperature of water and sediment samples was recorded using a thermometer.

\section{pH}

The $\mathrm{pH}$ of water and sediment samples was measured by a pH meter (ELICO - L1 - 612).

\section{Turbidity}

Turbidity of water samples was measured using Nephelometer (Systronics Model - 132).

\section{Salinity}

Salinity of the water and sediment samples were measured by a Salinity Refractometer (Atago Model S/Mill - E) (Ochsenreiter et al., 2002).

\section{Alkalinity}

Alkalinity of water and sediments were measured by potentiometric titration method.

\section{Total hardness}

Total hardness was estimated by EDTA titrimetric method.

\section{TDS}

The total dissolved solids were measured by a TDS meter.

\section{Chloride}

The chloride content was estimated by argentometric method.

\section{Calcium}

The calcium content was estimated by EDTA titrimetric method.

\section{Magnesium}

Magnesium was estimated as the difference between hardness and calcium as $\mathrm{CaCO}_{3}$.

\section{Sodium}

Sodium content was determined by a Flame-photometer (Systronics Model - 128).

\section{Potassium}

The potassium content was measured by a Flamephotometer (Systronics Model-128).

\section{Sulfate}

Sulfate concentration was measured spectrophotometrically by turbidimetric method using $\mathrm{Bacl}_{2}$.

\section{Phosphate}

The phosphate content of water and sediments was estimated by stannous chloride method.

\section{Statistical Analysis}

The data were subjected to Karl-Pearson correlation coefficient to examine the co-relationship between and among various physical and chemical parameters using SPSS. 15.0.

\section{RESULTS AND DISCUSSION}

The results of various physical and chemical parameters of water and sediments at Newport and Nari are as presented in Tables 1-4. Figures 3 and 4 indicate a comprehensive comparison of various parameters at sites Newport and Nari.

The temperature of the water and sediment samples at Newport ranged between 25 and $41^{\circ} \mathrm{C}$ and at Nari from 21 to $37^{\circ} \mathrm{C}$. The highest temperature range for both the

Table 1: Physico-chemical parameters of water from salt pans at Newport

\begin{tabular}{lccc}
\hline Parameters & December 2005 & April 2006 & August 2006 \\
\hline Temperature $\left({ }^{\circ} \mathrm{C}\right)$ & $26 \pm 2.081$ & $40 \pm 2.081$ & $30 \pm 1.154$ \\
$\mathrm{pH}$ & $8 \pm 0.46$ & $8 \pm 0.58$ & $7 \pm 0.00$ \\
Turbidity $(\mathrm{NTU})$ & $19 \pm 7.39$ & $33 \pm 2.61$ & $6 \pm 1.43$ \\
Salinity $(\%)$ & $315 \pm 11.54$ & $330 \pm 10$ & $233 \pm 13.25$ \\
Alkalinity $(\mathrm{mg} / \mathrm{l})$ & $2166 \pm 144.3$ & $2333 \pm 381.81$ & $450 \pm 2.12$ \\
Total hardness $(\mathrm{g} / \mathrm{l})$ & $115 \pm 29.08$ & $132 \pm 6.00$ & $40 \pm 13.95$ \\
Total dissolved solids $(\mathrm{g} / \mathrm{l})$ & $315 \pm 11.54$ & $330 \pm 10$ & $233 \pm 60.27$ \\
Chloride $(\mathrm{g} / \mathrm{l})$ & $176 \pm 33.6$ & $221 \pm 55.8$ & $107 \pm 29.6$ \\
Calcium $(\mathrm{g} / \mathrm{l})$ & $0.77 \pm 0.32$ & $0.89 \pm 0.12$ & $0.71 \pm 0.318$ \\
Magnesium $(\mathrm{g} / \mathrm{l})$ & $14 \pm 4.27$ & $22 \pm 5.19$ & $5 \pm 7.58$ \\
Sodium $(\mathrm{g} / \mathrm{l})$ & $92 \pm 2.64$ & $99 \pm 1.154$ & $62 \pm 5.84$ \\
Potassium $(\mathrm{g} / \mathrm{l})$ & $6 \pm 2.17$ & $7 \pm 5.25$ & $4 \pm 1.62$ \\
Sulfate $(\mathrm{g} / \mathrm{l})$ & $6.48 \pm 28.9$ & $12 \pm 0.529$ & $4 \pm 0.01$ \\
Phosphate $(\mu \mathrm{g} / \mathrm{l})$ & $32 \pm 11.6$ & $18 \pm 6.35$ & $3 \pm 1.74$ \\
\hline
\end{tabular}

\pm SD - The values represent mean of triplicates. SD: Standard deviation 
Table 2: Physico-chemical parameters of water from salt pans at Nari

\begin{tabular}{lccc}
\hline Parameters & December 2005 & April 2006 & August 2006 \\
\hline Temperature $\left({ }^{\circ} \mathrm{C}\right)$ & $20 \pm 0.00$ & $35 \pm 1.52$ & $30 \pm 1.41$ \\
$\mathrm{pH}$ & $7 \pm 1.06$ & $7 \pm 0.135$ & $6 \pm 0.07$ \\
Turbidity (NTU) & $13 \pm 0.62$ & $21 \pm 1.63$ & $5 \pm 3.25$ \\
Salinity $(\%)$ & $280 \pm 20$ & $310 \pm 5.77$ & $75 \pm 7.07$ \\
Alkalinity $(\mathrm{mg} / \mathrm{l})$ & $3000 \pm 419.3$ & $5817 \pm 11.6$ & $1250 \pm 0.00$ \\
Total hardness $(\mathrm{g} / \mathrm{l})$ & $68 \pm 19.51$ & $126 \pm 15.2$ & $14 \pm 4.2$ \\
Total dissolved solids $(\mathrm{g} / \mathrm{l})$ & $280 \pm 20$ & $310 \pm 5.77$ & $75 \pm 5$ \\
Chloride $(\mathrm{g} / \mathrm{l})$ & $172 \pm 25.9$ & $200 \pm 62.3$ & $30 \pm 7.7$ \\
Calcium $(\mathrm{g} / \mathrm{l})$ & $3 \pm 0.99$ & $5 \pm 0.81$ & $1 \pm 0.65$ \\
Magnesium $(\mathrm{g} / \mathrm{l})$ & $27 \pm 17.55$ & $31 \pm 1.51$ & $9 \pm 3.57$ \\
Sodium $(\mathrm{g} / \mathrm{l})$ & $82 \pm 2.51$ & $87 \pm 7.54$ & $25 \pm 6.92$ \\
Potassium $(\mathrm{g} / \mathrm{l})$ & $3 \pm 1.13$ & $5 \pm 1.80$ & $2 \pm 0.3$ \\
Sulfate $(\mathrm{g} / \mathrm{l})$ & $2.95 \pm 0.01$ & $10 \pm 0.01$ & $0.19 \pm 0.00$ \\
Phosphate $(\mu \mathrm{g} / \mathrm{l})$ & $14 \pm 5.03$ & $12 \pm 5.60$ & $0.004 \pm 0.02$ \\
\hline
\end{tabular}

\pm SD - The values represent mean of triplicates. SD: Standard deviation

Table 3: Physico-chemical parameters of sediments from salt pans at Newport

\begin{tabular}{lccc}
\hline Parameters & December 2005 & April 2006 & August 2006 \\
\hline Temperature $\left({ }^{\circ} \mathrm{C}\right)$ & $25 \pm 0.57$ & $41 \pm 0.57$ & $32 \pm 1$ \\
$\mathrm{pH}$ & $7.5 \pm 0.43$ & $8.3 \pm 0.37$ & $7 \pm 0.1$ \\
Salinity $(\%)$ & $43 \pm 1.5$ & $90 \pm 3.2$ & $20 \pm 1.01$ \\
Alkalinity $(\mathrm{mg} / \mathrm{kg})$ & $0.0034 \pm 0.001$ & $0.013 \pm 0.003$ & $0.0038 \pm 0.003$ \\
Total hardness $(\mathrm{g} / \mathrm{kg})$ & $1183 \pm 1.19$ & $18000 \pm 1.8$ & $2133 \pm 1.02$ \\
Total dissolved & $43 \pm 1.5$ & $90 \pm 1.01$ & $28 \pm 1.2$ \\
solids $(\mathrm{g} / \mathrm{kg})$ & & & \\
Chloride $(\mathrm{g} / \mathrm{kg})$ & $0.006 \pm 0.002$ & $0.08 \pm 0.005$ & $0.003 \pm 0.00$ \\
Calcium $(\mathrm{g} / \mathrm{kg})$ & $0.4 \pm 0.1$ & $0.11 \pm 0.05$ & $0.1 \pm 0.08$ \\
Magnesium $(\mathrm{g} / \mathrm{kg})$ & $33 \pm 9.16$ & $11 \pm 2$ & $0.9 \pm 0.00$ \\
Sodium $(\mathrm{g} / \mathrm{kg})$ & $8 \pm 0.51$ & $12 \pm 0.48$ & $2 \pm 1$ \\
Potassium $(\mathrm{g} / \mathrm{kg})$ & $0.7 \pm 0.15$ & $1.2 \pm 0.08$ & $0.3 \pm 0.15$ \\
Sulfate $(\mathrm{g} / \mathrm{kg})$ & $8 \pm 0.17$ & $24 \pm 3.5$ & $6 \pm 0.8$ \\
Phosphate $(\mu \mathrm{g} / \mathrm{g})$ & $0.56 \pm 0.25$ & $0.89 \pm 0.10$ & $0.45 \pm 0.05$ \\
\hline
\end{tabular}

\pm SD - The values represent mean of triplicates. SD: Standard deviation

Table 4: Physico-chemical parameters of sediments from salt pans at Nari

\begin{tabular}{lccc}
\hline Parameters & December 2005 & April 2006 & August 2006 \\
\hline Temperature $\left({ }^{\circ} \mathrm{C}\right)$ & $21 \pm 1.52$ & $37 \pm 1.15$ & $32 \pm 1.76$ \\
$\mathrm{pH}$ & $7 \pm 0.30$ & $7.6 \pm 0.56$ & $7 \pm 1.7$ \\
Salinity $(\%)$ & $67 \pm 1.25$ & $78 \pm 5.7$ & $38 \pm 2.8$ \\
Alkalinity $(\mathrm{mg} / \mathrm{kg})$ & $0.002 \pm 0.001$ & $0.010 \pm 0.002$ & $0.0022 \pm 0.001$ \\
Total hardness $(\mathrm{g} / \mathrm{kg})$ & $5600 \pm 10.5$ & $6866 \pm 12.1$ & $320 \pm 11.5$ \\
Total dissolved & $67 \pm 5.2$ & $78 \pm 5.77$ & $20 \pm 2.82$ \\
solids $(\mathrm{g} / \mathrm{kg})$ & & & \\
Chloride $(\mathrm{g} / \mathrm{kg})$ & $0.003 \pm 0.00$ & $0.008 \pm 0.00$ & $0.001 \pm 0.00$ \\
Calcium $(\mathrm{g} / \mathrm{kg})$ & $0.6 \pm 0.26$ & $0.22 \pm 0.06$ & $0.1 \pm 0.01$ \\
Magnesium $(\mathrm{g} / \mathrm{kg})$ & $81 \pm 3.6$ & $29.33 \pm 1.5$ & $1.9 \pm 1$ \\
Sodium $(\mathrm{g} / \mathrm{kg})$ & $5 \pm 1.00$ & $8 \pm 0.90$ & $1 \pm 0.07$ \\
Potassium $(\mathrm{g} / \mathrm{kg})$ & $0.25 \pm 0.05$ & $0.52 \pm 0.01$ & $0.15 \pm 0.07$ \\
Sulfate $(\mathrm{g} / \mathrm{kg})$ & $5 \pm 0.69$ & $14 \pm 3.7$ & $3 \pm 0.35$ \\
Phosphate $(\mu \mathrm{g} / \mathrm{g})$ & $0.25 \pm 0.06$ & $0.52 \pm 0.06$ & $0.11 \pm 0.005$ \\
\hline
\end{tabular}

$\pm S D$ - The values represent mean of triplicates. SD: Standard deviation

samples at Newport was $40-41^{\circ} \mathrm{C}$ and $35-37^{\circ} \mathrm{C}$ at Nari in April 2006, followed by $30-32^{\circ} \mathrm{C}$ in August 2006 at both the sites (Tables 1-4, Figures 3 and 4). Thus, the temperatures of water and sediment at Newport was higher than Nari, and the temperature of sediments was

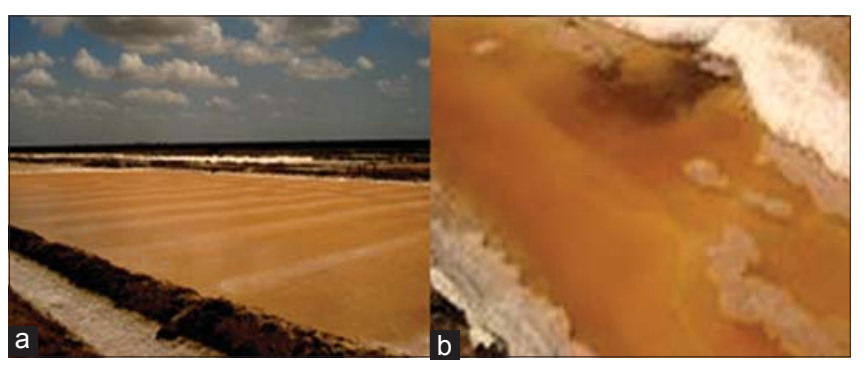

Figure 2: Red colored salt pans at the site of study (a) Newport (b) Nari

slightly higher than water. $\mathrm{pH}$ of water and sediment samples at Newport ranged between 7-8.3 and at Nari 6-7.6 (Tables 1-4, Figures 3 and 4). It is evident from the results that $\mathrm{pH}$ of water and sediments were slightly alkaline in the month of April and in December while they were found to be neutral in August. The $\mathrm{pH}$ of the sediment was more alkaline as compared to water. Furthermore, $\mathrm{pH}$ of water and sediment samples was higher at Newport than at Nari. The turbidity ranged from 6 to 33 NTU at Newport and 5-21 NTU at Nari (Tables 1 and 2 and Figure 3). Turbidity was higher in April 2006 followed by December 2005 and August 2006. The water samples at site Newport were found to be more turbid when compared to Nari.

Salinity at Newport for water and sediment ranged from 20 to $330 \%$ and at Nari from 38 to $310 \%$ (Tables 1-4, Figures 3 and 4 ). The results indicate that salinity of water was higher as compared to sediments and salinity of both water and sediments were higher at Newport than Nari. Alkalinity ranged between 450 and $5817 \mathrm{mg} / \mathrm{l}$ for water sample at Newport and Nari and 0.002-0.013 mg/ $\mathrm{kg}$ for sediment samples (Tables 1-4, Figures 3 and 4). Alkalinity was higher in water samples as compared to sediments, whereas alkalinity was higher at Nari when compared to Newport. Hardness of water sample ranged between 14 and $132 \mathrm{~g} / \mathrm{l}$ at both the sites. Whereas hardness of sediment samples ranged from 2133 to $18,000 \mathrm{~g} / \mathrm{kg}$ for both sites (Tables 1-4, Figures 3 and 4). It is thus evident that in contrast to the previous parameters total hardness was higher in sediments as compared to water and it was higher at Newport than Nari.

TDS values at Newport ranged from 75 to $330 \mathrm{~g} / \mathrm{l}$ for Newport and Nari. Whereas values for sediments samples ranged from 20 to $90 \mathrm{~g} / \mathrm{l}$ (Tables 1-4, Figures 3 and 4). Thus, from the above results, TDS were higher in water than sediments, and the values were higher at Newport than at Nari.

Chloride content of water ranged between 30 and $221 \mathrm{~g} / \mathrm{l}$ at Newport and Nari. Chloride content in sediment 


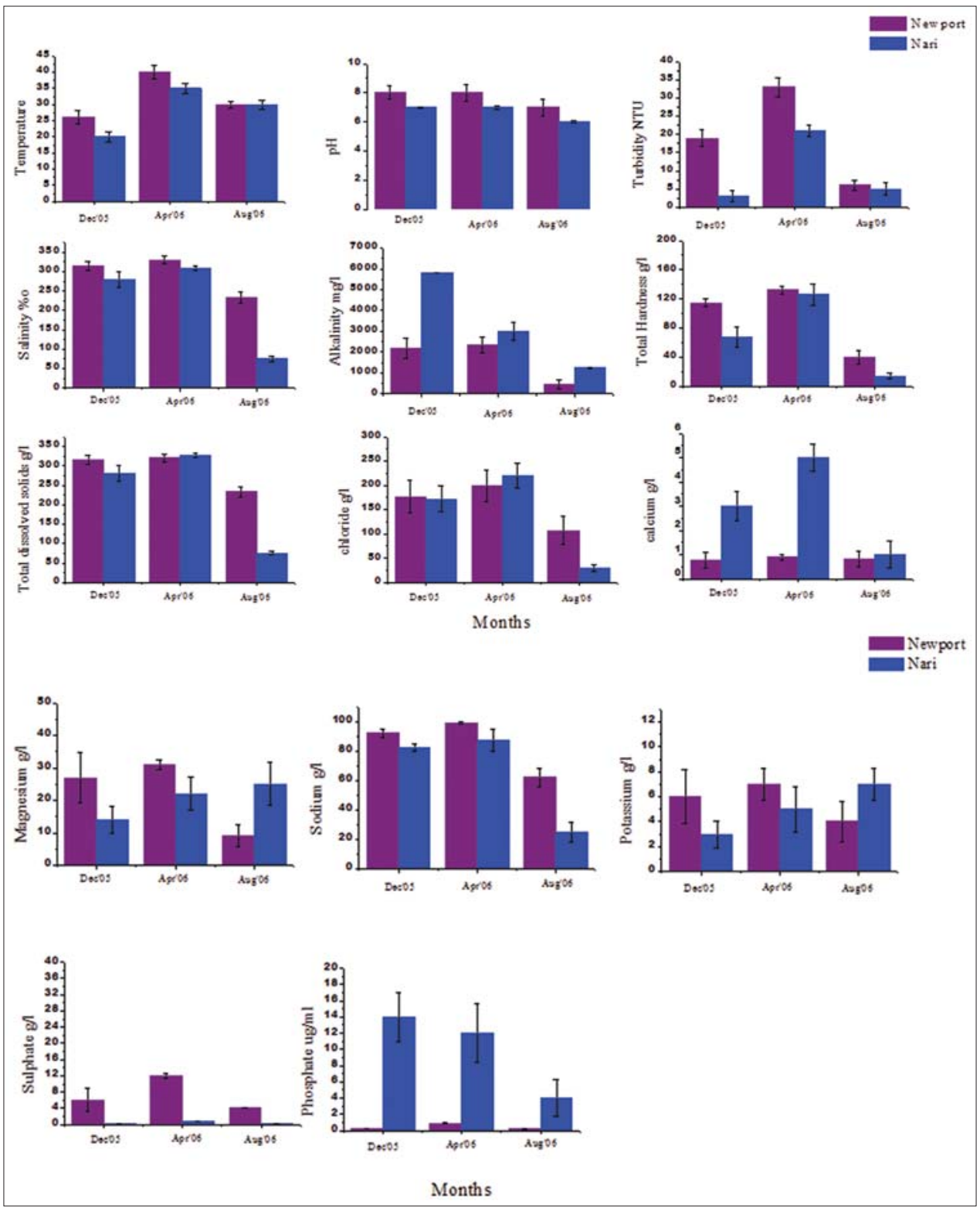

Figure 3: Physico-chemical parameters of water from salt pans at Newport and Nari

ranged between 0.001 and $0.08 \mathrm{~g} / \mathrm{kg}$ for both the sites (Tables 1-4, Figures 3 and 4). Chloride content in water was higher than sediments, and Newport possessed higher chloride content as compared to Nari. Calcium content varied from 0.71 to $5 \mathrm{~g} / \mathrm{l}$ at both the sites. While in sediments sample it ranged from 0.1 to $0.6 \mathrm{~g} / \mathrm{kg}$ (Tables 1-4, Figures 3 and 4). It is thus evident that the calcium content was higher in water as compared to sediments. In contrast, to all previous parameters examined, calcium content at Nari was slightly higher than at Newport. Magnesium content ranged from 5 to $31 \mathrm{~g} / \mathrm{l}$ at Newport and Nari. Maximum content recorded was $22 \mathrm{~g} / \mathrm{l}$ at Newport and $31 \mathrm{~g} / \mathrm{l}$ at Nari. Magnesium content of sediments at Newport ranged from 1.9 to $81 \mathrm{~g} / \mathrm{kg}$ for both the sites. Maximum values were
$33 \mathrm{~g} / \mathrm{kg}$ at Newport and $81 \mathrm{~g} / \mathrm{kg}$ at Nari (Tables 1-4, Figures 3 and 4 ). The results suggested that the content of magnesium was higher in water than sediments and Nari had higher magnesium content than Newport. Furthermore, maximum content recorded in sediments was in December 2005.

Sodium content ranged between $25-99 \mathrm{~g} / \mathrm{l}$ at Newport and 25-87 g/l. Sodium content in the sediments varied from 2 to $12 \mathrm{~g} / \mathrm{kg}$ at Newport and $1-8 \mathrm{~g} / \mathrm{kg}$ at Nari (Tables $1-4$, Figures 3 and 4 ). Maximum values were $12 \mathrm{~g} / \mathrm{kg}$ at Newport and $8 \mathrm{~g} / \mathrm{kg}$ at Nari. Thus, sodium content was higher in water than sediments and the content was higher at Newport than at Nari. Potassium content in water at Newport fluctuated between $4-7 \mathrm{~g} / \mathrm{l}$ and $2-5 \mathrm{~g} / \mathrm{l}$ at 


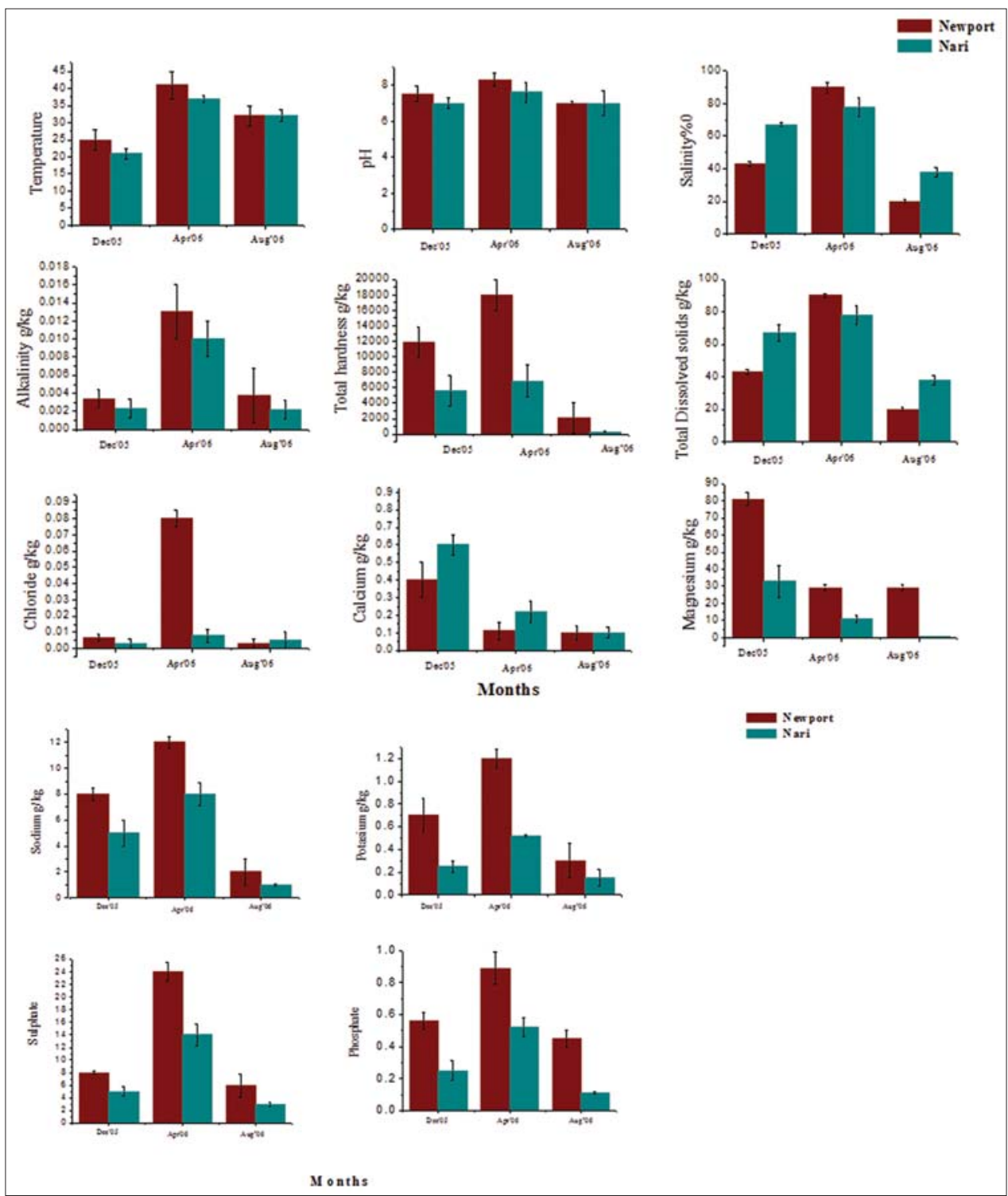

Figure 4: Physico-chemical parameters of sediments from salt pans at New Port and Nari

Nari. The potassium content in sediment varied between $0.3-1.2 \mathrm{~g} / \mathrm{kg}$ at Newport and $0.15-0.52 \mathrm{~g} / \mathrm{kg}$ at Nari (Tables 1-4, Figures 3 and 4). Thus, water possessed higher content of potassium as compared to sediments and the content at Newport was higher than at Nari. Sulfate content at Newport varied between 0.19 and $12 \mathrm{~g} / \mathrm{l}$. Sulfate content in the sediments ranged from 6 to $24 \mathrm{~g} / \mathrm{kg}$ at Newport and 3-14 g/ kg at Nari (Tables 1-4, Figures 3 and 4). Thus, the content of sulfate recorded was higher in sediments compared to water, and the content was higher at Newport than Nari. Phosphate content for water varied between 0.04 and $32 \mu \mathrm{g} / \mathrm{l}$ for both the sites. For sediment, it varied from 0.11 to $0.89 \mu \mathrm{g} / \mathrm{g}$ at Newport and Nari (Tables 1-4, Figures 3 and 4). Thus, water possessed higher content of phosphate at Newport compared to Nari in all the three seasons.

\section{Statistical Analyses}

\section{Correlation among the physical and chemical parameters of water and sediments at site Newport and Nari}

Tables 5 and 6 indicate correlation between the various physical and chemical parameters of water and sediments at Newport as analyzed by Karl-Pearson correlation coefficient. The results indicated a significant positive correlation between the temperature of water and most of the parameters examined, except phosphate. $\mathrm{pH}$ also exhibited a significant positive correlation with all the parameters examined as above except a significant negative correlation with turbidity. Whereas, alkalinity, hardness, TDS, sodium, potassium, sulfate, and phosphate individually exhibited a significant positive correlation with all the parameters examined (Table 5). The 
temperature of sediments at Newport showed a positive correlation with most of the parameters examined except calcium and magnesium. $\mathrm{pH}$, salinity, and alkalinity showed correlation with all parameters except a significant negative correlation with calcium. Chloride, potassium, sulfate, and phosphate also showed significant negative correlation with calcium and magnesium, whereas positive with the rest of the parameters (Table 6).

Tables 7 and 8 indicate correlation between the physical and chemical parameters of water and sediments at Nari. The temperature of water at Nari showed positive significant correlation with most of the parameters examined except magnesium and phosphate. $\mathrm{pH}$, turbidity, salinity, hardness, TDS, chloride, calcium, sodium, potassium, sulfate, and phosphate individually exhibited a positive significant correlation with all the parameters, whereas alkalinity showed significant negative correlation with sulfate (Table 7). With sediments, all the parameters individually showed a significant positive correlation with each other except temperature with hardness, calcium, and magnesium; $\mathrm{pH}$ with calcium, magnesium; hardness with temperature; chloride with calcium; and calcium with temperature, $\mathrm{pH}$, alkalinity, chloride, potassium, and sulfate (Table 8).

There are reports by Kamal et al., 2007 and Bhandari and Nayal, 2007 on correlation studies of water and soil of aquatic bodies. However, the present study of the correlation between various physico-chemical parameters relating to the hypersaline environment does not find support as the available literature does not provide any. Thus, the present study can provide valuable information on the relationship between physico-chemical and extremophilic microbiological components of the salt pans.

\section{CONCLUSION}

Having defined Archaea as a new domain, Woese redrew the taxonomic tree. In his three domain system Bacteria, Archaea, and Eukarya, Archaea have been associated with extreme environments and, although today they are recognized as normal inhabitants of other non-extreme environments, they constitute a large proportion of the microbial biota of hypersaline environments. In

Table 5: Correlation coefficient among various physical and chemical parameters of water at Newport

\begin{tabular}{|c|c|c|c|c|c|c|c|c|c|c|c|c|c|c|}
\hline Parameters & 1 & 2 & 3 & 4 & 5 & 6 & 7 & 8 & 9 & 10 & 11 & 12 & 13 & 14 \\
\hline Temperature & 1 & $0.240 *$ & $0.183 *$ & 0.377 * & $0.317 *$ & $0.405^{*}$ & $0.377 *$ & $0.601 *$ & $0.817^{*}$ & $0.669 *$ & 0.409 * & $0.545^{*}$ & $0.866^{*}$ & $-0.258^{*}$ \\
\hline $\mathrm{pH}$ & $0.240 *$ & 1 & $-0.998^{*}$ & 0.990 * & 0.997 * & $0.985^{*}$ & $0.990 *$ & 0.920 * & 0.756 * & $0.882 *$ & 0.984 * & $0.945^{*}$ & $0.693 *$ & $0.876 *$ \\
\hline Turbidity & $0.183 *$ & $-0.998 *$ & 1 & 0.980 * & 0.990 * & $0.973 *$ & $0.980 *$ & 0.896 * & $0.716 *$ & $0.853 *$ & $0.972 *$ & 0.924 * & 0.650 * & $0.903 *$ \\
\hline Salinity & $0.377 *$ & $0.990 *$ & $0.980 *$ & 1 & $0.998 *$ & $1.000 *$ & $1.000 * *$ & $0.967 *$ & $0.842 *$ & 0.941 * & $0.999 *$ & $0.982 *$ & $0.790 *$ & $0.797^{*}$ \\
\hline Alkalinity & $0.317 *$ & 0.997 * & 0.990 * & $0.998 *$ & 1 & 0.996 * & $0.998 *$ & $0.948 *$ & 0.806 * & $0.917^{*}$ & $0.995 *$ & 0.968 * & $0.749 *$ & $0.834 *$ \\
\hline Hardness & $0.405^{*}$ & $0.985^{*}$ & $0.973 *$ & $1.000 *$ & 0.996 * & 1 & $1.000 *$ & $0.974 *$ & $0.858 *$ & 0.951 * & $1.000 * *$ & 0.987 * & $0.808 *$ & $0.779 *$ \\
\hline TDS & $0.377 *$ & $0.990 *$ & $0.980 *$ & $1.000 * *$ & $0.998 *$ & 1.000 & 1 & $0.967 *$ & $0.842 *$ & 0.941 * & $0.999 *$ & $0.982 *$ & $0.790 *$ & $0.797^{*}$ \\
\hline Chloride & $0.601 *$ & 0.920 * & 0.896 * & $0.967 *$ & $0.948 *$ & $0.974 *$ & 0.967 * & 1 & $0.952 *$ & $0.996 *$ & $0.975^{*}$ & $0.998 *$ & $0.920 *$ & $0.617^{*}$ \\
\hline Calcium & $0.817 *$ & 0.756 * & $0.716 *$ & $0.842 *$ & 0.806 * & $0.858 *$ & $0.842 *$ & $0.952 *$ & 1 & $0.975^{*}$ & $0.860 *$ & $0.929 *$ & $0.996 *$ & $0.346 *$ \\
\hline Magnesium & $0.669 *$ & $0.882^{*}$ & $0.853 *$ & 0.941 * & 0.917 * & $0.951 *$ & 0.941 * & $0.996 *$ & $0.975 *$ & 1 & $0.952 *$ & $0.988 *$ & 0.951 * & $0.546 *$ \\
\hline Sodium & $0.409 *$ & 0.984 * & $0.972 *$ & $0.999 *$ & $0.995^{*}$ & $1.000 * *$ & $0.999 *$ & $0.975^{*}$ & 0.860 * & $0.952 *$ & 1 & $0.988^{*}$ & 0.811 * & $0.776 *$ \\
\hline Potassium & $0.545^{*}$ & $0.945^{*}$ & $0.924 *$ & $0.982 *$ & $0.968 *$ & $0.987 *$ & $0.982 *$ & $0.998 *$ & $0.929 *$ & $0.988^{*}$ & $0.988 *$ & 1 & $0.891 *$ & $0.670 *$ \\
\hline Sulfate & $0.866 *$ & 0.693 * & 0.650 * & 0.790 * & $0.749 *$ & $0.808 *$ & 0.790 * & 0.920 * & 0.996 * & 0.951 * & 0.811 * & 0.891 * & 1 & $0.259 *$ \\
\hline Phosphate & $-0.258 *$ & 0.876 * & $0.903 *$ & 0.797 * & $0.834 *$ & $0.779 *$ & 0.797 * & 0.617 * & $0.346 *$ & $0.546 *$ & 0.776 * & 0.670 * & $0.259 *$ & 1 \\
\hline
\end{tabular}

*Correlation is significant at the 0.05 level (2-tailed). ${ }^{*}$ Correlation is significant at the 0.01 level (2-tailed). TDS: Total dissolved solids

Table 6: Correlation coefficient among various physical and chemical parameters of sediments at Newport

\begin{tabular}{|c|c|c|c|c|c|c|c|c|c|c|c|c|c|}
\hline Parameters & 1 & 2 & 3 & 4 & 5 & 6 & 7 & 8 & 9 & 10 & 11 & 12 & 13 \\
\hline Temperature & 1 & $0.665^{*}$ & 0.711 * & $0.915 *$ & $0.451 *$ & $0.711 *$ & 0.880 * & $-0.811 *$ & $-0.586 *$ & $0.462 *$ & $0.613 *$ & $0.851 *$ & $0.769 *$ \\
\hline $\mathrm{pH}$ & $0.665^{*}$ & 1 & $0.998 *$ & $0.910 *$ & $0.966 *$ & $0.998 *$ & 0.940 * & $-0.103 *$ & $0.214^{*}$ & 0.970 * & $0.998 *$ & $0.958 *$ & $0.989 *$ \\
\hline Salinity & $0.711 *$ & $0.998 *$ & 1 & $0.934 *$ & $0.948 *$ & $1.000 * *$ & 0.960 * & $-0.165^{*}$ & $0.152 *$ & $0.952 *$ & 0.991 * & $0.974 *$ & $0.996 *$ \\
\hline Alkalinity & $0.915 *$ & 0.910 * & $0.934^{*}$ & 1 & $0.772 *$ & $0.934 *$ & 0.997 * & $-0.506 *$ & $-0.210 *$ & $0.780 *$ & $0.879 *$ & $0.990 *$ & $0.961 *$ \\
\hline Hardness & 0.451 * & 0.966 * & $0.948 *$ & $0.772 *$ & 1 & $0.948 *$ & $0.820 *$ & $0.157 *$ & $0.459 *$ & $1.000 * *$ & $0.982 *$ & $0.853 *$ & $0.918 *$ \\
\hline TDS & $0.711 *$ & $0.998 *$ & $1.000 * *$ & $0.934 *$ & $0.948 *$ & 1 & 0.960 * & $-0.165^{*}$ & $0.152 *$ & $0.952 *$ & 0.991 * & $0.974 *$ & $0.996 *$ \\
\hline Chloride & $0.880 *$ & $0.940 *$ & $0.960 *$ & $0.997 *$ & 0.820 * & $0.960 *$ & 1 & -0.436 * & $-0.132 *$ & $0.828^{*}$ & $0.914^{*}$ & $0.998 *$ & $0.980 *$ \\
\hline Calcium & $-0.811^{*}$ & $-0.103 *$ & $-0.165^{*}$ & $-0.506 *$ & $0.157^{*}$ & $-0.165^{*}$ & $-0.436 *$ & 1 & $0.950 *$ & $0.144^{*}$ & $-0.035^{*}$ & $-0.383 *$ & $-0.249 *$ \\
\hline Magnesium & $-0.586^{*}$ & $0.214^{*}$ & $0.152 *$ & $-0.210 *$ & $0.459 *$ & $0.152^{*}$ & $-0.132 *$ & $0.950 *$ & 1 & 0.447 * & $-0.281^{*}$ & $-0.074^{*}$ & $0.067 *$ \\
\hline Sodium & $0.462 *$ & 0.970 * & 0.952 * & $0.780 *$ & $1.000 * *$ & $0.952 *$ & $0.828^{*}$ & $0.144^{*}$ & $0.447 *$ & 1 & $0.984 *$ & $0.859 *$ & $0.923 *$ \\
\hline Potassium & $0.613 *$ & $0.998 *$ & 0.991 * & $0.879 *$ & $0.982 *$ & 0.991 * & 0.914 * & $-0.035^{*}$ & $-0.281 *$ & $0.984 *$ & 1 & 0.937 * & $0.977^{*}$ \\
\hline Sulfate & $0.851 *$ & $0.958 *$ & $0.974 *$ & $0.990 *$ & $0.853 *$ & $0.974 *$ & $0.998 *$ & $-0.383 *$ & $-0.074^{*}$ & $0.859 *$ & $0.937^{*}$ & 1 & $0.990 *$ \\
\hline Phosphate & $0.769 *$ & 0.989 * & 0.996 * & 0.961 * & $0.918 *$ & 0.996 * & 0.980 * & $-0.249 *$ & $0.067^{*}$ & $0.923 *$ & $0.977^{*}$ & $0.990 *$ & 1 \\
\hline
\end{tabular}

*Correlation is significant at the 0.05 level (2-tailed). **Correlation is significant at the 0.01 level (2-tailed). TDS: Total dissolved solids 
Table 7: Correlation coefficient among various physical and chemical parameters of water at Nari

\begin{tabular}{|c|c|c|c|c|c|c|c|c|c|c|c|c|c|c|}
\hline Parameters & 1 & 2 & 3 & 4 & 5 & 6 & 7 & 8 & 9 & 10 & 11 & 12 & 13 & 14 \\
\hline Temperature & 1 & $0.143 *$ & 0.327 * & $0.073 *$ & $0.750 *$ & $0.347 *$ & $0.073 *$ & $0.036 *$ & $0.327^{*}$ & $-0.019 *$ & $0.117^{*}$ & $0.500 *$ & $0.695 *$ & $-0.371 *$ \\
\hline $\mathrm{pH}$ & $0.143 *$ & 1 & $0.982 *$ & $0.977^{*}$ & $0.548 *$ & $0.978 *$ & $0.977^{*}$ & $0.984 *$ & $0.982 *$ & $0.987^{*}$ & 0.966 * & $0.929 *$ & 0.811 * & $0.866 *$ \\
\hline Turbidity & $0.327 *$ & $0.982 *$ & 1 & $0.919 *$ & $0.380 *$ & $1.000 *$ & $0.919 *$ & $0.933 *$ & $1.000 * *$ & $0.939 *$ & $0.900 *$ & $0.982 *$ & 0.907 * & $0.756^{*}$ \\
\hline Salinity & $0.073 *$ & $0.977^{*}$ & $0.919 *$ & 1 & $0.714^{*}$ & $0.910 *$ & $1.000 * *$ & $0.999 *$ & $0.919 *$ & $0.999 *$ & $0.999 *$ & 0.827 * & $0.666^{*}$ & $0.953 *$ \\
\hline Alkalinity & $0.750 *$ & $0.548 *$ & 0.380 * & $0.714^{*}$ & 1 & $0.361 *$ & $0.714^{*}$ & $0.688 *$ & $0.380 *$ & $0.675^{*}$ & $0.745^{*}$ & $0.198 *$ & $-0.046 *$ & $0.893 *$ \\
\hline Hardness & 0.347 * & $0.978 *$ & $1.000 *$ & $0.910 *$ & $0.361 *$ & 1 & $0.910 *$ & $0.925 *$ & $1.000 *$ & 0.931 * & 0.891 * & $0.986 *$ & $0.915^{*}$ & $0.742 *$ \\
\hline TDS & $0.073 *$ & $0.977^{*}$ & $0.919 *$ & $1.000 * *$ & $0.714^{*}$ & $0.910 *$ & 1 & $0.999 *$ & $0.919 *$ & $0.999 *$ & $0.999 *$ & 0.827 * & 0.666 * & $0.953 *$ \\
\hline Chloride & $0.036 *$ & 0.984 * & $0.933 *$ & 0.999* & $0.688 *$ & $0.925 *$ & $0.999 *$ & 1 & $0.933 *$ & $1.000 *$ & 0.997 * & $0.848^{*}$ & 0.693 * & $0.941 *$ \\
\hline Calcium & $0.327^{*}$ & $0.982 *$ & $1.000 * *$ & $0.919 *$ & $0.380 *$ & $1.000 *$ & $0.919 *$ & $0.933 *$ & 1 & 0.939 * & 0.900 * & $0.982 *$ & 0.907 * & $0.756^{*}$ \\
\hline Magnesium & $-0.019 *$ & $0.987 *$ & $0.939 *$ & $0.999 *$ & $0.675^{*}$ & 0.931 * & $0.999 *$ & $1.000 *$ & $0.939 *$ & 1 & $0.995 *$ & $0.857^{*}$ & $0.706 *$ & $0.935^{*}$ \\
\hline Sodium & $0.117 *$ & 0.966 * & 0.900 * & $0.999 *$ & $0.745^{*}$ & $0.891 *$ & $0.999 *$ & $0.997 *$ & $0.900 *$ & $0.995^{*}$ & 1 & $0.801 *$ & $0.632 *$ & $0.966 *$ \\
\hline Potassium & $0.500 *$ & $0.929 *$ & $0.982 *$ & $0.827 *$ & $0.198 *$ & $0.986 *$ & $0.827^{*}$ & $0.848 *$ & $0.982 *$ & $0.857 *$ & $0.801 *$ & 1 & 0.970 * & $0.619 *$ \\
\hline Sulfate & $0.695^{*}$ & 0.811 * & 0.907 * & 0.666 * & $-0.046 *$ & $0.915^{*}$ & 0.666 * & $0.693 *$ & $0.907^{*}$ & $0.706 *$ & $0.632 *$ & 0.970 * & 1 & $0.409 *$ \\
\hline Phosphate & $-0.371^{*}$ & $0.866^{*}$ & $0.756 *$ & $0.953 *$ & $0.893 *$ & $0.742 *$ & $0.953 *$ & $0.941 *$ & $0.756 *$ & $0.935^{*}$ & 0.966 * & $0.619 *$ & $0.409 *$ & 1 \\
\hline
\end{tabular}

*Correlation is significant at the 0.05 level (2-tailed). **Correlation is significant at the 0.01 level (2-tailed). TDS: Total dissolved solids

Table 8: Correlation coefficient among various physical and chemical parameters of sediments at Nari

\begin{tabular}{|c|c|c|c|c|c|c|c|c|c|c|c|c|c|}
\hline Parameters & 1 & 2 & 3 & 4 & 5 & 6 & 7 & 8 & 9 & 10 & 11 & 12 & 13 \\
\hline Temperature & 1 & 0.741 * & 0.056 * & $0.733 *$ & $-0.030 *$ & 0.056 * & $0.525 *$ & $-0.857^{*}$ & $-0.812^{*}$ & $0.226 *$ & $0.539 *$ & $0.615^{*}$ & $0.472^{*}$ \\
\hline $\mathrm{pH}$ & 0.741 * & 1 & $0.712 *$ & $1.000 * *$ & $0.650 *$ & $0.712^{*}$ & 0.961 * & $-0.288 *$ & $-0.209 *$ & $0.822 *$ & $0.965^{*}$ & $0.985^{*}$ & $0.942 *$ \\
\hline Salinity & $0.056 *$ & $0.712^{*}$ & 1 & $0.720 *$ & 0.996 * & $1.000 * *$ & $0.879 *$ & $0.467^{*}$ & $0.537^{*}$ & $0.985^{*}$ & 0.871 * & $0.822 *$ & $0.907^{*}$ \\
\hline Alkalinity & $0.733^{*}$ & $1.000 * *$ & $0.720 *$ & 1 & $0.658 *$ & $0.720 *$ & 0.964 * & $-0.277^{*}$ & $-0.198 *$ & $0.828 *$ & 0.968 * & $0.987 *$ & $0.946^{*}$ \\
\hline Hardness & $-0.030 *$ & $0.650 *$ & $0.996 *$ & $0.658 *$ & 1 & 0.996 * & $0.835^{*}$ & $0.541^{*}$ & $0.608 *$ & $0.967 *$ & 0.826 * & $0.770 *$ & $0.867 *$ \\
\hline TDS & $0.056 *$ & $0.712 *$ & $1.000 * *$ & $0.720 *$ & 0.996 * & 1 & $0.879 *$ & $0.467 *$ & $0.537^{*}$ & $0.985^{*}$ & 0.871 * & $0.822 *$ & $0.907^{*}$ \\
\hline Chloride & $0.525^{*}$ & $0.961 *$ & $0.879 *$ & $0.964 *$ & $0.835^{*}$ & $0.879 *$ & 1 & $-0.011 *$ & $0.070 *$ & $0.948 *$ & $1.000 *$ & $0.994^{*}$ & $0.998 *$ \\
\hline Calcium & $-0.857^{*}$ & $-0.288^{*}$ & 0.467 * & $-0.277^{*}$ & 0.541 * & $0.467 *$ & $-0.011 *$ & 1 & $0.997 *$ & $0.309 *$ & $-0.027^{*}$ & $-0.120 *$ & $0.051 *$ \\
\hline Magnesium & $-0.812^{*}$ & $-0.209 *$ & $0.537 *$ & $-0.198 *$ & $0.608 *$ & $0.537^{*}$ & $0.070 *$ & $0.997 *$ & 1 & $0.385^{*}$ & $0.053 *$ & $-0.039 *$ & $0.131 *$ \\
\hline Sodium & $0.226 *$ & $0.822^{*}$ & $0.985 *$ & $0.828 *$ & 0.967 * & $0.985^{*}$ & $0.948 *$ & $0.309 *$ & $0.385 *$ & 1 & $0.942 *$ & $0.907 *$ & 0.966 * \\
\hline Potassium & $0.539 *$ & $0.965 *$ & $0.871^{*}$ & $0.968 *$ & 0.826 * & $0.871^{*}$ & $1.000 *$ & $-0.027^{*}$ & $0.053 *$ & $0.942 *$ & 1 & $0.996 *$ & $0.997^{*}$ \\
\hline Sulfate & $0.615^{*}$ & $0.985^{*}$ & $0.822 *$ & $0.987 *$ & 0.770 * & $0.822 *$ & 0.994 * & $-0.120 *$ & $-0.039 *$ & $0.907^{*}$ & 0.996 * & 1 & $0.985^{*}$ \\
\hline Phosphate & $0.472 *$ & $0.942 *$ & $0.907^{*}$ & $0.946 *$ & $0.867^{*}$ & 0.907 * & $0.998 *$ & $0.051 *$ & $0.131 *$ & $0.966 *$ & 0.997 * & $0.985^{*}$ & 1 \\
\hline
\end{tabular}

${ }^{*}$ Correlation is significant at the 0.05 level (2-tailed). ${ }^{*}$ Correlation is significant at the 0.01 level (2-tailed). TDS: Total dissolved solids

hypersaline habitats, especially those in which salinities exceed $1.5 \mathrm{M}$, the two main groups of microorganisms that predominate are the moderately halophilic bacteria and the extremely halophilic Archaea.

The physical and chemical environment is important for many of the processes that take place both in biotic and abiotic environments. Based on concentrations of various physical and chemical constituents such as nutrients and trace elements, the energy conversion level from phase to phase and the production of organic matter for direct utilization by organisms can be found out. Thus, as there is a distinct interrelationship existing between physico-chemical and microbiological components of the aquatic ecosystem (Venugopalam and Paulpandian, 1989; Kennedy, 1995), the study on physico-chemical characterization of hypersaline environments had been taken up. The data also were statistically analyzed for their correlation by Karl-Pearson correlation that determined significance between and among various parameters, which has probably not been attempted for halophilic Archaea inhabiting hypersaline environments.

\section{REFERENCES}

APHA (American Public Health Association). Standard Methods for the Examination of Water and Wastewater, WEF and AWWA. 20 ${ }^{\text {th }}$ ed. USA: American Public Health Association; 2005.

Bhandari NS, Nayal K. Correlation study on physico-chemical parameters and quality assessment of Kosi river water, Uttarakhand. E J Chem 2007;5:342-6.

BrockTD. Ecology of saline lakes. In: Shilo M, editor. Strategies of Microbial Life in Extreme Environments. Berlin: Dahlem Konferenzen; 1979. p. 29-47.

Charatkar SL, Mitra D, Biradar RS, Pikle M. Study of salt pan increment in Gulf of Cambay using GIS Paper Presented at $25^{\text {th }}$ Annual ESRI User International Conference at San Diego, California, USA, July 25-29 2005.

Gunde-Cimerman N, Zalar P, Hoog S, Plemenitas A. Hypersaline waters in salterns-natural ecological niches for halophilic black yeasts. FEMS Microbiol Ecol 2000;32:235-40.

Kamal D, Khan AN, Rahman MA, Ahamed F. Study on the physico-chemical properties of water of Mouri River, Khulna, Bangladesh. Pak J Biol Sci 2007;10:710-7.

Kennedy AC, Smith KL. Soil microbial diversity and 
the sustainability of agricultural soils. Plant Soil 1995;170:75-86.

Le Borgne S, Paniagua D, Vazquez-Duhalt R. Biodegradation of organic pollutants by Halophilic bacteria and Archaea. J Mol Microbiol Biotechnol 2008;15:74-92.

Ochsenreiter T, Pfeifer F, Schleper C. Diversity of Archaea in hypersaline environments characterized by molecularphylogenetic and cultivation studies. Extremophiles 2002;6:267-74.

Ollivier B, Caumette P, Garcia JL, Mah R. Anaerobic bacteria from hypersaline environments. Microbiol Rev 1994;58:27-38.

Pedrós-Alió C, Calderó-Paz I, MacLean H, Medina G, Marrase C, Gasol M, et al. The microbial food web along salinity gradients. FEMS Microbiol Ecol 2000;32:143-55.

Pedrós-Alió C. Trophic ecology of solar salterns. In: Ventosa A, editor. Halophilic Microorganisms. Heidelberg: SpringerVerlag; 2004. p. 33-48.

Venugopalam VK, Paulpandian AL. Methods in hydrobiology. In: CAS in Marine Biology. India: Annamalai University Publications; 1989. p. 1-134. 